\title{
Hepato-protective effects and chemical constituents of a bioactive fraction of the traditional compound medicine-Gurigumu-7
}

\author{
Haiyan Xu, Qiong Ma, Jiannan Ma, Zhigang Wu, Yali Wang and Chaomei Ma*
}

\begin{abstract}
Background: Gurigumu-7 is an important traditional Mongolian medicine frequently used for liver diseases. However, the pharmacological effects and the bioactive constituents are not well understood.

Method: This research was to use $\mathrm{CCl}_{4}$-induced liver damage in mice to investigate the hepatoprotective effects of Gurigumu-7 and the methanol eluted fraction from a DIAION column of an extract of Gurigumu-7 (MF). The chemical constituents of MF were analyzed by UPLC-MS.

Results: Pretreated orally with MF $(66,132$ and $264 \mathrm{mg} / \mathrm{kg})$ once a day for 4 days dose-dependently suppressed $\mathrm{CCl}_{4}$-induced mice liver histopathological changes and serum aminotransferase activities (alanine transaminase: $1144.0 \pm 787.2$ v.s. $2461.8 \pm 1072.7 \mathrm{U} / \mathrm{L}, p<0.05$; aspartate transaminase: $1173 \pm 785.3$ v.s. $2506.6 \pm 1140.7 \mathrm{U} / \mathrm{L}, p<0.01$ ). MF treated group demonstrated increased levels of SOD $(108.19 \pm 30.32$ v.s. $75.75 \pm 5.37 \mathrm{U} / \mathrm{mg}$ protein, $p<0.01)$ but decreased levels of malonyldialdehyde (7.68 \pm 1.95 v.s. $44.32 \pm 16.68 \mathrm{nmol} / \mathrm{mg}$ protein, $p<0.01)$ compared to the $\mathrm{CCl}_{4}$ control group. More than 30 chemical constituents were quantified, and MF was found to be rich in ellagic acid (297.97 mg/g), luteolin and its glucosides (35.10 mg/g), apigenin and its glucosides (>30 mg/g), ursolic acid (14.91 mg/g) , bidenoside C ( $8.75 \mathrm{mg} / \mathrm{g})$, and proanthocyanidins (15.64 mg/g in proanthocyanidin A2 equivalent).

Conclusion: The methanol eluted fraction (MF) from a DIAION column of an extract of the Mongolian medicine-Gurigumu-7 was found to be more hepatoprotective than Gurigumu-7. The results suggested that $M F$ is a promising bioactive fraction for the development of new hepatoprotective medicine with better formulation and quality control properties.
\end{abstract}

Keywords: Gurigumu-7, Hepatoprotective effect, Bioactive fraction, Bioactive constituents

\section{Background}

Gurigumu-7 is an ethnic compound medicine frequently used for liver diseases in the Mongolian and Tibetan traditional medical settings. It is comprised of seven individual traditional medicines, the flower of Carthamus tinctorius L. (Safflower), the fruit of Terminalia chebula Retz. (Fructus chebulae), the flower of Scabiosa comosa Fisch. ex Roem. \& Schult. (Flos scabiosae), the aerial part of Ephedra sinica Stapf (Herba ephedrae), the aerial part of Viola yezoensis Maxim. (Herba violae), gypsum and the caulis of Clematis armandii Franch (Caulis clematidis armandii).

\footnotetext{
* Correspondence: cmma@imu.edu.cn

Collage of Life Science, Inner Mongolia University, Huhhot, Inner Mongolia, China
}

Safflower is one of the most frequently used herbal liver injury [3]. Fructus chebulae has been used in traditional medicine for intestinal and hepatic detoxification, diarrhea, cough, sore throat and various ailments [4]. Fructus chebulae is rich in phenolic compounds which were reported to have anti-viral activities against hepatitis $C$ and other viruses [5-7]. Flos scabiosae is used mainly for liver diseases in traditional medicine [8]. Phenolics $[9,10]$ and triterpene compounds [11] were reported as the bioactive constituents of Flos scabiosae. Herba ephedrae has been used to relief symptoms of colds [12] due to 
the nasal decongesting and bronchodilating effects of its alkaloid constituents, ephedrine and related compounds. However, these sympathomimetic alkaloids may cause side effects to central nervous system. Renewed interest in herba ephedrae has come from new pharmacological findings that this herb could decrease uraemic toxins and showed anti-inflammatory activity due to its proanthocyanidin constituents [13-16]. Herba violae has been used for boils, carbuncles, hepatitis and other infections in traditional Chinese medicine [17]. The flavonoid constituents were reported to be the bioactive constituents of Herba violae for antibacterial and antioxidant activities [18-20]. Caulis clematidis armandii has been traditionally used mainly for inflammatory-associated diseases and the phenolic constituents were reported to be its bioactive constituents [21, 22]. Gurigumu-7 was reported have the effect to decrease serum aminotransferase activities in $\mathrm{CCl}_{4}$-induced mice [23]. However, the bioactive fraction, bioactive constituents and mechanism of action of Gurigumu-7 have not been revealed.

Composed of 7 raw materials, Gurigumu- 7 has to be administered in large volumes and the taste is unpleasant. Moreover, it is hard to establish a quality control method for Gurigumu-7, as each of the component herbal medicine could contain hundreds of chemical constituents. It is necessary to find out the bioactive fraction for the possibility to reduce the dosage and to simplify the quality control method. In the present study, we used macroporous resin to separate Gurigumu-7 extract to 3 fractions and tested the hepatoprotective effects of these fractions. The most active fraction, MF (methanol eluted fraction), was further investigated in detail for its in vivo protective effects on liver damage induced by carbon tetrachloride and compared the effect with Gurigumu-7. The chemical constituents, antioxidant activity and ability to increase liver antioxidase load of MF were also investigated.

\section{Methods}

\section{Chemicals and instruments}

Extraction solvents were of analytical grade from XiLong chemical Co. Ltd. (Guangdong, China). Silymarin was obtained from Sigma-Aldrich (SIGMA-ALDRICH, Co., China) and used as a positive control in this research. UPLC-DADESI-MS experiments were performed on an Agilent 1290 infinity UPLC system (Agilent, USA). Absorbance was measured with a microplate reader (DNM-9602, Beijing Pu Long new technology Co. Ltd., Beijing, China). A wan-neng pulverizer (Zhejiang Yi Li Co. Ltd., Zhejiang, China) was used for grinding medicines.

\section{Plant material}

The seven medicines to formulate Gurigumu-7 in this research were supplied by Kulun Mongolian medicine factory, Inner Mongolia, China and identified by the authors through examining the morphological characteristics, anlyzing the UHPLC-MS of the plant extracts, and considering the information provided by the supplier. The voucher specimens were stored in the Laboratory of Natural Products \& Functional Foods, College of Life Sciences, Inner Mongolia University, China, as followings: the flower of Carthamus tinctorius $\mathrm{L}$ (voucher specimen number NPFFC-2); the fruit of Terminalia chebula Retz (voucher specimen NPFFT-1); Gypsum (99.5\% of $\mathrm{CaSO}_{4} \cdot 2 \mathrm{H}_{2} \mathrm{O}$ content as determined by the method described in Chinese pharmacopeia, voucher specimen number NPFFG-1); the aerial part of Ephedra sinica Stapf (voucher specimen number NPFFE-1); the aerial part of Viola yezoensis Maxim (voucher specimen number NPFFV-1); the flower of Scabiosa comosa Fisch. ex Roem. \& Schult. (voucher specimen number NPFFS-1); the caulis of Clematis armandii Franch (voucher specimen number NPFFC-3).

\section{Preparation of samples}

Gurigumu-7 was prepared according to the documented prescription [1] by mixing the individual medicines in the following ratio: Safflower $25 \mathrm{~g}$ - Gypsum $15 \mathrm{~g}$ - Herba ephedrae $15 \mathrm{~g}$ - Herba violae $15 \mathrm{~g}$ - Fructus chebulae $15 \mathrm{~g}$ - Flos scabiosae $10 \mathrm{~g}$ - Caulis clematidis armandii $10 \mathrm{~g}$, and grinding the mixture to powder.

MF (methanol eluted fraction from a DIAION column of Gurigumu-7 extract) was prepared as following: Gurigumu-7 was extracted with methanol under reflux $\left(70{ }^{\circ} \mathrm{C}\right)$ for three times $(2 \mathrm{~h}, 1 \mathrm{~h}$ and $30 \mathrm{~min}$, respectively). The pooled methanol solution was concentrated under vacuum $\left(40{ }^{\circ} \mathrm{C}\right)$ to get the methanol extract (10.33 g) which was subjected to a macroporous resin (DIAION HP20) column eluted with $\mathrm{H}_{2} \mathrm{O}, \mathrm{H}_{2} \mathrm{O}-\mathrm{MeOH}$ 1:1 and $\mathrm{MeOH}$. The $\mathrm{MeOH}$ eluted part was concentrated under vacuum $\left(40{ }^{\circ} \mathrm{C}\right)$ to get $\mathrm{MF}$ as a brown powder $(1.78 \mathrm{~g})$.

\section{Animals and treatments}

Six-week-old male scxk (meng) 2002-0001 mice (weighing $30 \pm 5 \mathrm{~g}$ ) were purchased from the Animal Center of Inner Mongolia University, China. The mice were housed in clean cages accessing to food and water ad libitum and acclimated to the temperature $\left(22 \pm 2{ }^{\circ} \mathrm{C}\right)$ with $12 \mathrm{~h}$ light/dark cycles for one week. The animals were cared for in accordance with the "guidelines for animal experiments" and the experimental procedures were approved by the Animal Ethics Committee of Inner Mongolia University (approval number 2016004). One hundred and twenty mice were randomly divided into two groups named experiment 1 and 2 (e1 and e2). E1 and e2 were further randomly divided into six groups with ten mice in each group, respectively. Mice of groups 1 and 2 from e1 and e2 were given with $0.5 \mathrm{ml}$ saline/day, group 3 from e1 and e2 were given with $17 \mathrm{mg} / \mathrm{kg}$ silymarin. Groups 4, 5 and 6 
from e1 were treated with Gurigumu-7 powder (270.84, $541.68,1083.36 \mathrm{mg} / \mathrm{kg}$, respectively). Groups 4, 5 and 6 from e2 were treated with 66,132 and $264 \mathrm{mg} / \mathrm{kg}$ of MF, respectively. Each group received the appropriate vehicle or sample daily by gastric intubations for 4 days. After $1 \mathrm{~h}$ of the medication in the forth day, $\mathrm{CCl}_{4}(125 \mu \mathrm{l}, 1 \%$ in oil) was given by intraperitoneal injection to mice except for the mice in group 1 which were given oil only. Whole blood was collected for biochemical analysis from the orbit $16 \mathrm{~h}$ later after drug administration, and the liver tissue was cut and immediately fixed in $10 \%$ neutral formalin for histopathology study.

\section{Serum biochemistry}

The blood samples were put standing for one hour and the serum was separated by centrifugation (WiseSpin ${ }^{\circ}$ Personal Table Top Centrifuges, CF-10, DAIHAN Scientific, Co., Ltd) under $12225 \mathrm{~g}$ for $5 \mathrm{~min}$. Serum alanine transaminase (ALT) and aspartate transaminase (AST) were measured in Hospital of Inner Mongolia University using standard clinical method.

\section{Determination of malondialdehyde (MDA) and superoxide dismutase (SOD) in liver homogenate}

The liver tissue samples were homogenized with cold saline. The homogenates were centrifuged at $3000 \mathrm{rpm}$ at $4{ }^{\circ} \mathrm{C}$ for $10 \mathrm{~min}$ and the supernatant was kept at $-80{ }^{\circ} \mathrm{C}$ until use. The supernatant was used for the measurement of MDA and SOD using commercial kits (Jiancheng Institute of Biotechnology, Nanjing, China) following the supplier's instructions.

\section{Histological examinations}

Liver tissues from e2 were fixed in $10 \%(\mathrm{v} / \mathrm{v})$ neutral phosphate buffer formalin and the liver pathological section were prepared and examined by the First Affiliated Hospital of Inner Mongolia Medical University - Cancer Hospital.

\section{DPPH radical scavenging assay}

The DPPH scavenging activity of MF and the Gurigumu-7 extract were measured at the concentrations of 50, 25, $12.5,6.25,3.125 \mu \mathrm{g} / \mathrm{mL}$ using reported method [24]. Briefly, $10 \mu \mathrm{l}$ of sample solution in DMSO was mixed with $190 \mu \mathrm{l}$ of the ethanol solution of DPPH. After $20 \mathrm{~min}$, the absorbance (A) at $540 \mathrm{~nm}$ was measured and the percentage of DPPH scavenged (S\%) was calculated using the following formula:

$$
\mathrm{S} \%=100 \times\left(\mathrm{A}_{\text {control }}-\mathrm{A}_{\text {sample }}\right) / \mathrm{A}_{\text {control }}
$$

Where $A_{\text {control }}$ was the average absorbance of wells without sample.
Table 1 Effects of Gurigumu-7 powder on serum transaminases in $\mathrm{CCl}_{4}$-injured mice (e1)

\begin{tabular}{lll}
\hline Groups & \multicolumn{2}{l}{ Parameter (U/L) } \\
\cline { 2 - 3 } & ALT & AST \\
\hline Saline-treated mice & $32.1 \pm 8.4^{\# \# \#}$ & $141.6 \pm 59.0^{\# \#}$ \\
$\mathrm{CCl}_{4}$-treated mice & $3822.0 \pm 1494.8$ & $4059.6 \pm 1408.3$ \\
$\mathrm{CCl}_{4}-17 \mathrm{mg} / \mathrm{kg}$ silymarin-treated & $2205.0 \pm 912.2^{*}$ & $2034.0 \pm 1262.9^{*}$ \\
mice & & \\
$\mathrm{CCl}_{4}-270.84 \mathrm{mg} / \mathrm{kg}$ Gurigumu-7 & $3438.0 \pm 1742.0$ & $3586.0 \pm 2170.1$ \\
-treated mice & & \\
$\mathrm{CCl}_{4}-541.68 \mathrm{mg} / \mathrm{kg}$ Gurigumu-7 & $2933.2 \pm 1405.0$ & $2910.0 \pm 1652.8$ \\
-treated mice & & \\
$\mathrm{CCl}_{4}-1083.36 \mathrm{mg} / \mathrm{kg}$ Gurigumu-7 & $2345.1 \pm 1449.8$ & $2290.2 \pm 1519.7^{*}$ \\
-treated mice & & \\
\hline
\end{tabular}

The values are expressed as mean \pm S.D

*significant different $(p<0.05)$ from $\mathrm{CCl}_{4}$ control group

\#\#highly significant different $(p<0.01)$ from $\mathrm{CCl}_{4}$ control group

Results represented as $\mathrm{EC}_{50}$ (sample concentration that produced $50 \%$ of radical scavenging activity) were found from the $\mathrm{S} \%$-versus-concentration curves.

\section{Preparation of Sample Solutions for UPLC-DAD-MS Analysis} The 3 fractions of Gurigumu-7 were dissolved in DMSO $(10 \mu \mathrm{g}: 1 \mathrm{ml})$ containing $1 \mu \mathrm{g} / \mathrm{mL}$ of abrusin $2 "-O-\beta$ apioside [25] as internal standard. Standard stock solutions were prepared in DMSO containing $1 \mu \mathrm{g} / \mathrm{mL}$ of internal standard. The solutions were filtrated through $0.22 \mu \mathrm{m}$ microfilters to obtain the sample solutions for ultra-high performance liquid chromatography-diode array detector-triple quadruple mass spectrometry (UPLC-DADQQQMS) analysis.

\section{UPLC-DAD-QQQMS analysis}

The chemical compositions of the three fractions from a DIAION column chromatography of Gurigumu-7 were analyzed by UPLC-DAD-QQQMS using an Agilent ZORBAX SB-C18 RRHT column $(50 \times 2.1 \mathrm{~mm}$ i.d.; particle size $1.8 \mu \mathrm{m}$ ) at $30{ }^{\circ} \mathrm{C}$. The constituents were quantified by

Table 2 Effects of MF on serum transaminases in $\mathrm{CCl}_{4}$-injured mice (e2)

\begin{tabular}{lll}
\hline Groups & Parameter $(\mathrm{U} / \mathrm{L})$ & \\
\cline { 2 - 3 } & $\mathrm{ALT}$ & $\mathrm{AST}$ \\
\hline Saline-treated mice & $30.4 \pm 4.0^{\# \#}$ & $123.0 \pm 24.3^{\# \#}$ \\
$\mathrm{CCl}_{4}$-treated mice & $2461.8 \pm 1072.7$ & $2506.6 \pm 1140.7$ \\
$\mathrm{CCl}_{4}-17 \mathrm{mg} / \mathrm{kg}$ silymarin-treated & $1115.6 \pm 291.3^{* *}$ & $1230.6 \pm 437.6^{* *}$ \\
$\mathrm{mice}^{*}$ & & \\
$\mathrm{CCl}_{4}-66 \mathrm{mg} / \mathrm{kg} \mathrm{MF}$-treated mice & $2766.0 \pm 1909.7$ & $2482.8 \pm 1853.3$ \\
$\mathrm{CCl}_{4}-132 \mathrm{mg} / \mathrm{kg}$ MF-treated mice & $1929.0 \pm 799.8$ & $1748.0 \pm 694.8$ \\
$\mathrm{CCl}_{4}-264 \mathrm{mg} / \mathrm{kg}$ MF-treated mice & $1144.0 \pm 787.2^{*}$ & $1173 \pm 785.3^{* *}$ \\
\hline
\end{tabular}

The values are expressed as mean \pm S.D

*significant different $(p<0.05)$ from $\mathrm{CCl}_{4}$ control group

$\# \#_{* * *}$ highly significant different $(p<0.01)$ from $\mathrm{CCl}_{4}$ control group 
Table 3 Liver SOD and MDA levels in mouse treated with $\mathrm{CCl}_{4}$ and MF

\begin{tabular}{lll}
\hline Groups & $\mathrm{SOD}(\mathrm{U} / \mathrm{mg}$ protein) & $\mathrm{MDA}(\mathrm{nmol} / \mathrm{mg}$ protein) \\
\hline Saline-treated mice & $114.23 \pm 2.75^{\# \#}$ & $7.08 \pm 0.04^{\# \#}$ \\
$\mathrm{CCl}_{4}$-treated mice & $75.75 \pm 5.37$ & $44.32 \pm 16.68$ \\
$\mathrm{CCl}_{4}-17 \mathrm{mg} / \mathrm{kg}$ silymarin & $102.41 \pm 24.66^{*}$ & $12.47 \pm 3.27^{* *}$ \\
treated mice & \\
$\mathrm{CCl}_{4}-66 \mathrm{mg} / \mathrm{kg} \mathrm{MF}$ & $82.46 \pm 15.48$ & $19.31 \pm 6.58^{* *}$ \\
treated mice & \\
$\mathrm{CCl}_{4}-132 \mathrm{mg} / \mathrm{kg} \mathrm{MF}$ & $93.39 \pm 40.91$ & $8.58 \pm 1.11^{* *}$ \\
treated mice & \\
$\mathrm{CCl}_{4}-264 \mathrm{mg} / \mathrm{kg} \mathrm{MF}$ & $108.19 \pm 30.32^{* *}$ & $7.68 \pm 1.95^{* *}$ \\
treated mice & & \\
\hline
\end{tabular}

The values are expressed as mean \pm S.D

*significant different $(p<0.05)$ from $\mathrm{CCl}_{4}$ control group

$\# \#, * *$ highly significant different $(p<0.01)$ from $\mathrm{CCl}_{4}$ control group

UHPLC-QQQMS in multiple reaction monitoring (MRM) mode using reported analysis conditions and standard compounds for the constituents of Safflower [26, 27], Fructus chebulae [28], Flos scabiosae [10], Herba ephedrae [29], and Herba violae [20, 30]. For the quantification of calceorioside B in Caulis clematidis armandii, ESIMS full scan method was used and the extract was compared with a standard compound from Beijing Century Aoke Biotechnology Co. Ltd (Beijing, China). Data were presented as the average values from three repeat quantifications.

\section{Measurement of proanthocyanidin A2 equivalents}

Proanthocyanidin A2 equivalents were measured by n$\mathrm{BuOH}-\mathrm{HCl}-\mathrm{Fe}$ III method $[31,32]$. Briefly, to a $1.5 \mathrm{ml}$ centrifuge tube was added $0.5 \mathrm{mg}$ of sample, $1.2 \mathrm{ml}$ of a solution of $\mathrm{n}-\mathrm{BuOH}$-conc. $\mathrm{HCl}(95: 5, \mathrm{v} / \mathrm{v})$ and $40 \mu \mathrm{l}$ of ferric ammonium sulphate reagent $(2 \% \mathrm{w} / \mathrm{v}$ in $2 \mathrm{M}$ $\mathrm{HCl})$. The tubes were closely capped with top clips and heated at $95{ }^{\circ} \mathrm{C}$ for $40 \mathrm{~min}$. Absorbance of the released cyanidin was measured at $560 \mathrm{~nm}$ by a Thermo Scientific Varioskan Flash (Thermo Fisher Scientific Oy D.O. Box100, FI-01621 Vantaa, Finland). The flavan-3-ol contents were expressed as proanthocyanidin A2 equivalents as A-type proanthocyanidins were reported from one of the medicines in Gurigumu-7, Herba ephedrae $[15,16]$. Proanthocyanidin A2 equivalents of samples were calculated from the absorbance - concentration curve of proanthocyanidin A2.

\section{Statistical analysis}

Statistical analysis of the data was accomplished by mean of the $\mathrm{SPSS}^{\circledast}$ statistical software package. The data are presented as the means \pm SD. Differences where $P<0.05$ were considered statistically significant.

\section{Results}

The effect of gurigumu-7 and MF on the increased levels of serum transaminases induced with $\mathrm{CCl}_{4}$

As shown in Tables 1 and 2, the serum ALT and AST levels of $\mathrm{CCl}_{4}$-treated groups were significantly higher $(P<0.01)$ than saline-treated groups. In $\mathrm{e} 1$, the serum ALT and AST levels of mice treated with silymarin were lower $(P<0.05)$ than those treated with $\mathrm{CCl}_{4}$ only. Pretreatment with $1083.36 \mathrm{mg} \cdot \mathrm{kg}^{-1}$ of Gurigumu-7 powder

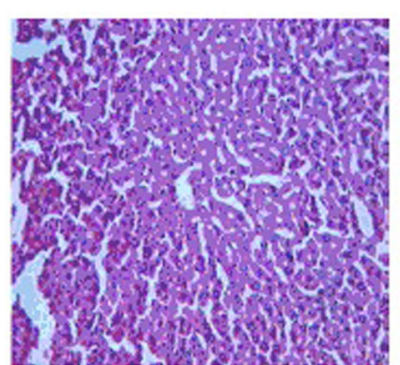

A

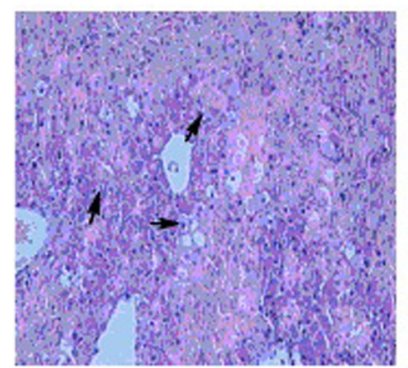

D

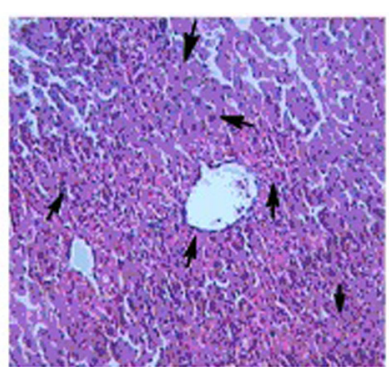

B

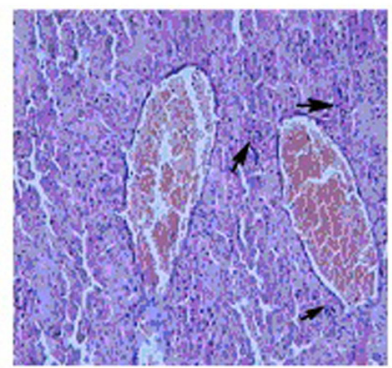

$\mathbf{E}$

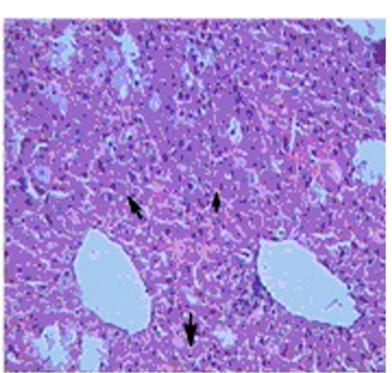

C

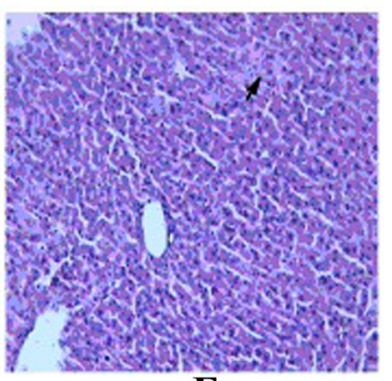

F

Fig. 1 Effects of silymarin and different doses of MF on the liver histological changes in $\mathrm{CCl}_{4}$ treatment mice. a normal group; b CCl - intoxicated group; c CCl + Silymarin (17 mg/kg); d CCl + MF (66 mg/kg); e CCl + MF (132 mg/kg). f CCl + MF (264 mg/kg) 
Table 4 Concentrations (mg/g unless otherwise indicated) of Gurigumu-7 constituents in the three fractions

\begin{tabular}{|c|c|c|c|c|}
\hline Main source & constituents & $\mathrm{H}_{2} \mathrm{O}$ fraction & 1:1 fraction & MF \\
\hline \multirow[t]{11}{*}{ Safflower } & protocatechuic acid & $0.00 \pm 0.00$ & $1.61 \pm 0.01$ & $1.15 \pm 0.00$ \\
\hline & hydroxysafflor yellow A & nd & $12.77 \pm 0.01$ & $0.19 \pm 0.02$ \\
\hline & 6-hydroxykaempfer 3,6,7-triglucoside & $0.17 \pm 0.00$ & $2.09 \pm 0.00$ & $0.08 \pm 0.01$ \\
\hline & kaempferol-3-O-D-glucoside & nd & $0.082 \pm 0.04$ & $3.13 \pm 0.01$ \\
\hline & bidenoside $C$ & nd & nd & $8.75 \pm 0.01$ \\
\hline & kaempferol-3-O-rutinocoside & $0.06 \pm 0.01$ & $0.65 \pm 0.05$ & $2.86 \pm 0.04$ \\
\hline & 6-hydroxykaempferol-3-rutinoside-6-glucoside & nd & $1.63 \pm 0.02$ & $0.22 \pm 0.02$ \\
\hline & 6-hydroxykaempferol-3,6-diglucoside & nd & $0.28 \pm 0.039$ & $0.04 \pm 0.03$ \\
\hline & linolic acid & nd & $0.21 \pm 0.03$ & $26.2 \pm 0.09$ \\
\hline & a-linolenic acid & nd & $0.20 \pm 0.08$ & $25.5 \pm 0.13$ \\
\hline & oleic acid & $0.36 \pm 0.07$ & $0.38 \pm 0.10$ & $3.13 \pm 0.09$ \\
\hline \multirow[t]{9}{*}{ Fructus chebulae } & chebulic acid & $12.81 \pm 0.02$ & $0.74 \pm 0.00$ & $0.076 \pm 0.00$ \\
\hline & gallic acid & $7.68 \pm 0.02$ & $12.23 \pm 0.02$ & nd \\
\hline & chebumeinin A & $0.09 \pm 0.00$ & $0.67 \pm 0.01$ & $0.09 \pm 0.00$ \\
\hline & chebumeinin B & $0.24 \pm 0.01$ & $0.48 \pm 0.01$ & $0.24 \pm 0.01$ \\
\hline & casuarinin & nd & $2.35 \pm 0.01$ & $1.88 \pm 0.01$ \\
\hline & corilagin & $3.48 \pm 0.01$ & $7.30 \pm 0.02$ & $3.50 \pm 0.02$ \\
\hline & chebulagic acid & $2.25 \pm 0.01$ & $6.05 \pm 0.01$ & $2.38 \pm 0.01$ \\
\hline & pentagalloyl glucose & $0.86 \pm 0.01$ & $1.06 \pm 0.01$ & $0.94 \pm 0.02$ \\
\hline & ellagic acid & nd & $82.14 \pm 0.80$ & $297.97 \pm 1.84$ \\
\hline \multirow[t]{16}{*}{ Flos scabiosae } & caffeic acid & nd & $0.46 \pm 0.00$ & nd \\
\hline & quinic acid & nd & $2.28 \pm 0.01$ & nd \\
\hline & chlorogenic acid & $0.87 \pm 0.01$ & $32.08 \pm 0.58$ & $0.83 \pm 0.02$ \\
\hline & p-coumaric acid & $0.24 \pm 0.00$ & $0.34 \pm 0.00$ & $0.67 \pm 0.01$ \\
\hline & luteolin-6-C-glucoside & nd & $5.54 \pm 0.01$ & $0.64 \pm 0.01$ \\
\hline & quercetin-3-glucoside & nd & $0.98 \pm 0.01$ & $4.30 \pm 0.01$ \\
\hline & rutin & nd & nd & $0.05 \pm 0.00$ \\
\hline & apigenin-7-arabinoglucoside & nd & $0.75 \pm 0.00$ & $5.38 \pm 0.02$ \\
\hline & apigenin-4'-glucoside & nd & nd & $11.59 \pm 0.02$ \\
\hline & apigenin-7-glucoside & nd & nd & $11.51 \pm 0.01$ \\
\hline & luteolin-4'-O-glucoside & nd & $0.73 \pm 0.00$ & $16.02 \pm 0.02$ \\
\hline & luteolin-7-O-glucoside & nd & $0.84 \pm 0.01$ & $16.12 \pm 0.02$ \\
\hline & luteolin & nd & nd & $2.96 \pm 0.02$ \\
\hline & apigenin & nd & nd & $1.59 \pm 0.01$ \\
\hline & ursolic acid & nd & nd & $14.91 \pm 0.35$ \\
\hline & hederagenin/3ß,23-dihydroxyursan-12-en-28-oic acid & $0.01 \pm 0.019$ & $0.01 \pm 0.02$ & $1.80 \pm 0.03$ \\
\hline \multirow[t]{2}{*}{ Herba ephedrae } & Ephadra alkaloids & nd & $98.33 \pm 0.15 \%^{\mathrm{a}}$ & $1.67 \pm 0.64 \%^{\mathrm{a}}$ \\
\hline & Proanthocyanidin A2 equivalent & nd & $31.33 \pm 2.62$ & $15.64 \pm 1.78$ \\
\hline \multirow[t]{3}{*}{ Herba violae } & 6,7-dihydroxycoumarin & nd & $25.23 \pm 0.74$ & $3.12 \pm 0.02$ \\
\hline & 5,5'-bi (6,7-dihydroxycoumarin) & nd & $0.67 \pm 0.01$ & nd \\
\hline & apigenin 6,8-di-C- $\beta$-D-glucoside, & $0.54 \pm 0.53 \%^{\mathrm{a}}$ & $90.81 \pm 1.01 \%^{\mathrm{a}}$ & $8.65 \pm 0.87 \%^{a}$ \\
\hline
\end{tabular}


Table 4 Concentrations (mg/g unless otherwise indicated) of Gurigumu-7 constituents in the three fractions (Continued)

\begin{tabular}{|c|c|c|c|c|}
\hline & $\begin{array}{l}\text { apigenin 6-C- } \beta \text {-D-glucosyl-8-C- } \alpha \text {-L-arabinoside/apigenin } \\
6-C-\beta \text { - D- glucosyl-8-C- } \beta \text {-L-arabinoside }\end{array}$ & $2.88 \pm 0.36 \%^{a}$ & $48.96 \pm 0.08 \%^{\mathrm{a}}$ & $48.16 \pm 0.65 \%^{2}$ \\
\hline & $\begin{array}{l}\text { apigenin 6-C- } \alpha \text {-L-arabinosyl- 8-C- } \beta \text {-D-xyloside/apigenin } \\
6,8-\text { di-C- } \alpha \text { - }- \text {-arabinoside }\end{array}$ & $2.66 \pm 0.08 \%^{a}$ & $47.50 \pm 0.45 \%^{a}$ & $49.83 \pm 0.71 \%$ \\
\hline Caulis clematidis armandii & calceolarioside B & & $0.18 \pm 0.89$ & $0.17 \pm 0.07$ \\
\hline
\end{tabular}

nd not detectable

apercentages of these compounds were calculated according to the peak area ratios of the compounds in LC-MS

significantly decreased the AST level $(p<0.05)$. Gurigumu-7 was separated by DIAION column chromatography to obtain three fractions and the methanol eluted fraction, MF, was found to be the most effective fraction in reducing serum transaminases, in a preliminary animal experiment. MF was then investigated in detail in e2 and the results are shown in Table 2. Pre-administration of MF to mice for four days at 66,132 and $264 \mathrm{mg} / \mathrm{kg}$ reduced the elevation of serum ALT and AST levels dose dependently. The serum ALT and AST levels in the $264 \mathrm{mg} / \mathrm{kg}$ MF-treated group were significantly lower ( $p<0.05$ and $p<0.01$, respectively) than $\mathrm{CCl}_{4}$-treated group.

\section{Effects on Superoxide Dismutase (SOD) and Malondialdehyde (MDA) levels}

In order to evaluate the effects of MF on $\mathrm{CCl}_{4}$ induced liver oxidative stress, we examined the mouse liver levels of SOD and MDA. SOD is an important antioxidant enzyme produced by living organisms to defense oxidative stress [33]. MDA is produced by lipid peroxidation and its level correlates with the degree of oxidative stress. The liver SOD and MDA levels are shown in Table 3. $\mathrm{CCl}_{4}$ treatment significantly decreased SOD activity and increased MDA content $(P<0.01)$, suggesting strong oxidative stress and lipid peroxidation in the $\mathrm{CCl}_{4}$ treated group. Pretreatment with MF (66, 132 and $264 \mathrm{mg} / \mathrm{kg})$ and silymarin prevented this trend. The SOD levels in both silymarin treated group and MF treated groups (264 mg/ $\mathrm{kg}$ ) were significantly increased compared with the $\mathrm{CCl}_{4}$ control group, and the MF treated group have better activities. Pre-administration with silymarin and MF caused highly significant decreases in the liver level of MDA $(P<0.01)$.

\section{Histopathological changes of mice livers}

The microscopic pictures of the mice liver tissue section are shown in Fig. 1. The cells of normal group (group 1, Fig. 1a) were arranged regularly without obvious degeneration and necrosis. In $\mathrm{CCl}_{4}$-intoxicated group (group 2, Fig. 1b), the liver lobule was around the central vein and there was a wide range of focal necrosis with inflammatory cell and degeneration. In the positive control group (group 3, Fig. 1c), the cells were cloudy swelling, but the structure was intact. As the dose of MF increased (Fig. 1d, e, f), the morphological changes became less.

\section{Components of MF}

More than 30 chemical constituents were quantified by UHPLC-QQQMS and colorimetric method for MF and the other two fractions from the DIAION column. The results are listed in Table 4. MF was found to be especially rich in ellagic acid $(297.97 \mathrm{mg} / \mathrm{g})$, luteolin and its glucosides $(35.10 \mathrm{mg} / \mathrm{g})$, apigenin and its glucosides $(30.07 \mathrm{mg} / \mathrm{g})$, ursolic acid $(14.91 \mathrm{mg} / \mathrm{g})$, and bidenoside C $(8.75 \mathrm{mg} / \mathrm{g})$. Among these, the triterpene compound ursolic acid (a major constituent of Flos scabiosae) and the acetylenic compound bidenoside C (a constituent of Safflower) were found exclusively in MF. MF also contained large amount of proanthocyanidins $(15.64 \mathrm{mg} / \mathrm{g}$ in proanthocyanidin A2 equivalent) that may come from Herba ephedrae, a plant known to contain A-type proanthocyanidins [16]. It is interesting to note that almost all ephedra alkaloids (98.33\%) were eluted out to the $\mathrm{H}_{2} \mathrm{O}-\mathrm{MeOH}$ 1:1 fraction, leaving MF almost free of ephedrine and related alkaloids.

MF demonstrated stronger DPPH scavenging activity $\left(\mathrm{EC}_{50}=39.79 \mu \mathrm{g} / \mathrm{mL}\right)$ than Gurigumu-7 extract $\left(\mathrm{EC}_{50}=\right.$ $43.69 \mu \mathrm{g} / \mathrm{mL}$ ), which may come from the high contents of phenolic compounds such as ellagic acid and the flavonoids, luteolin and its glucosides, as well as apigenin and its glucosides in MF (Table 5).

\section{Discussion}

The ethnic compound medicine, Gurigumu-7, has a long history to be used for liver diseases in Mongolian and Tibetan medical clinics [1]. The formulations of Gurigumu-7 on the market are bitter and astringent powder or bolus with a large dosage indicated ( $5 \mathrm{~g}$ every time for example). They are unpleasant to swallow and the administration may affect appetites. In this study, we separated Gurigumu-7 extract into three fractions by DIAION column and found MF, the methanol eluted fraction, demonstrated better bioactivity than Gurigumu-7. From $10.33 \mathrm{~g}$ of Gurigumu-7 extract, $1.78 \mathrm{~g}$ of MF was obtained, and indeed, a much lower dose $(264 \mathrm{mg} / \mathrm{kg})$ of MF showed more potent hepato-protective activity than Gurigumu-7 at $1083.36 \mathrm{mg} / \mathrm{kg}$. These results indicated that MF is one of the hepato-protective fractions of 
Table 5 DPPH scavenging activity of a methanolic extract of Gurigumu-7 and MF

\begin{tabular}{|c|c|c|c|c|c|c|}
\hline \multirow[t]{2}{*}{ Substance } & \multicolumn{5}{|c|}{ percentage of DPPH scavenged at different concentration } & \multirow{2}{*}{$\begin{array}{l}\mathrm{EC}_{50} \\
(\mu \mathrm{g} / \\
\mathrm{mL})\end{array}$} \\
\hline & $3.125 \mu \mathrm{g} / \mathrm{mL}$ & $6.25 \mu \mathrm{g} / \mathrm{mL}$ & $12.5 \mu \mathrm{g} / \mathrm{mL}$ & $25 \mu \mathrm{g} / \mathrm{mL}$ & $50 \mu \mathrm{g} / \mathrm{mL}$ & \\
\hline methanolic extract of Gurigumu-7 & 4.2 & 10.1 & 20.6 & 31.6 & 55.4 & 43.7 \\
\hline MF & 8.0 & 9.4 & 17.9 & 38.8 & 59.3 & 39.8 \\
\hline protocatechuic acid (positive control) & 30.4 & 44.4 & 58.7 & 72.2 & 81.7 & 7.8 \\
\hline
\end{tabular}

$\mathrm{MF}$ is the methanol eluted fraction from a DIAION column of Gurigumu-7 extract

gurigumu-7, and that administration of MF could reduce the effective dose.

It is reported that liver tissue in $\mathrm{CCl}_{4}$ treated animals can cause lipid peroxidation and trigger production of MDA. Measurement of MDA levels is the most commonly used method for the evaluation of lipid peroxidation, because MDA is the most abundant individual aldehyde resulting from lipid peroxidation [34]. Our study showed that acute $\mathrm{CCl}_{4}$ treatment caused an increase of liver MDA concentration which was in agreement with reported result [35]. Pretreatment with MF at the doses of $66,132,264 \mathrm{mg} / \mathrm{kg}$ for four consecutive days reversed these changes. SOD which is an important in vivo antioxidant enzyme is inactivated by lipid peroxides or reactive oxygen species when $\mathrm{CCl}_{4}$ is administrated [36]. In the MF treated groups, a tendency of dose-dependentincrease of SOD activities was observed, with the effect of $264 \mathrm{mg} \cdot \mathrm{kg}^{-1}$ being highly significant $(P<0.01)$. The strong DPPH scavenging activity of MF, and the increased liver SOD and decreased liver MDA levels of MF treated groups suggest that the hepatoprotective effects of MF are partly due to its antioxidant effects.

Chemical analysis revealed that MF contained large amounts of triterpene compound-ursolic acid, as well as phenolic compounds-ellagic acid and flavonoids (glycosides of apigenin, luteolin and quercetin). All these natural products are known to have hepatoprotective activities [37-39]. The active fraction of Gurigumu 7, MF, with better antioxidant and hepatoprotective activity in a much less dosage than Gurigumu 7, could be a better choice for patients.

\section{Conclusions}

In conclusion, this study demonstrated for the first time that the methanol eluted fraction (MF) from a DIAION column of an extract of the Mongolian medicinal prescription-Gurigumu-7 has hepatoprotective effect. MF dose dependently decreased serum aminotransferase activities, increased liver SOD levels and decreased liver malonyldialdehyde levels in $\mathrm{CCl}_{4}$ treated mice. MF was found to contain large amounts of bioactive phenolic compounds and triterpenes which might act concertedly for the hepatoprotective effects. The research results provided scientific evidence for the clinic efficacy of this Mongolian medicinal prescription for liver diseases. The results demonstrated that MF is a promising bioactive fraction of Gurigumu-7 for the develpment of convenient hepatoprotective formulations.

\begin{abstract}
Abbreviations
A, absorbance; ALT, alanine transaminase; AST, aspartate transaminase; EC50, $50 \%$ effective concentration; MDA, malonyldialdehyde; MF, the methanol eluted fraction from a DIAION column of an extract of Gurigumu-7; MRM, multiple reaction monitoring; SOD, superoxide dismutase; UPLC-DAD-QQQMS, ultra-high performance liquid chromatography-diode array detector-triple quadruple mass spectrometry
\end{abstract}

\section{Acknowledgements}

We would like to express our sincere thanks Liu Yang and Qianqian He for helping with the animal experiment. We would also like to thank the Hospital of Inner Mongolia University and the First Affiliated Hospital of Inner Mongolia Medical University - cancer hospital for caring out serum ALT, AST and pathological assessments.

\section{Funding}

This work was supported by the National Natural Science Foundation of China (No. 81160511).

\section{Availability of data and materials}

The data and materials of this article are included within the article.

\section{Authors' contributions}

CMM and HYX designed the study and wrote the paper; HYX, QM, JNM, ZGW and YLW performed the experiments. HYX and CMM analyzed data. All authors read and approved the final version of the manuscript.

\section{Competing interests}

The authors declare that they have no competing interests.

\section{Consent for publication}

Not applicable.

\section{Ethics approval and consent to participate}

The animals were cared for in accordance with the "guidelines for animal experiments" and the experimental procedures were approved by the Animal Ethics Committee of Inner Mongolia University (approval number 2016004).

Received: 29 August 2015 Accepted: 3 June 2016

Published online: 13 June 2016

References

1. Chinese Pharmacopoeia Committee. Drug standards of Ministry of public health of China (Mongolian medicine Fascicule). Beijing: Chemical Industry Press; 1998. p. 194.

2. Yang DH, Ren XL, Xu F, Ma X-Q, Liu G-X, Li C-H, Li C, Cai S-Q. Absorptive constituents and their metabolites in drug-containing urine samples from Wuzhishan miniature pigs orally administered with Buyang Huanwu decoction. J Nat Med. 2014;68:11-21.

3. Wang Y, Tang C, Zhang H. Hepatoprotective effects of kaempferol 3-Orutinoside and kaempferol 3-O-glucoside from Carthamus tinctorius L. on $\mathrm{CCl}_{4}$-induced oxidative liver injury in mice. J Food Drug Anal. 2015;23:310-7.

4. China Pharmacopoeia Committee. Pharmacopoeia of the People's Republic of China, vol. 1. Beijing: Chemical Industry Press; 2010. p. 173-4.

5. Pellati F, Bruni R, Righi D, Grandini A, Tognolini M, Pio Prencipe F, Poli F, Benvenuti S, Del Rio D, Rossi D. Metabolite profiling of polyphenols in a 
Terminalia chebula Retzius ayurvedic decoction and evaluation of its chemopreventive activity. J Ethnopharmacol. 2013;147:277-85.

6. Ajala OS, Jukov A, Ma C-M. Hepatitis C virus inhibitory hydrolysable tannins from the fruits of Terminalia chebula. Fitoterapia. 2014;99:117-23.

7. Lin LT, Chen TY, Lin SC, Chun CY, Lin TC, Wang GH, Anderson R, Lin CC, Richardson CD. Broad-spectrum antiviral activity of chebulagic acid and punicalagin against viruses that use glycosaminoglycans for entry. BMC Microbiol. 2013;13:187-202.

8. Chinese Pharmacopoeia Committee. Drug standards of Ministry of public health of China (Mongolian medicine Fascicule). Beijing: Chemical Industry Press; 1998. p. 52.

9. Wang G, Zhao Z, Xue P, Ma F, Zhang D, Wang N, Li M. Chemical constituents from flowers of Scabiosa tschilliensis. Zhongguo Zhong yao za zhi. 2015:40:807-13

10. Ma J-N, Bolraa S, Ji M, He Q-Q, Ma C-M. Quantification and antioxidant and anti-HCV activities of the constituents from the inflorescences of Scabiosa comosa and S. Tschilliensis. Nat Prod Res. 2016;30:590-4.

11. Ji M, Li SJ, Ma CM. Chemical constituents of the inflorescence of Scabiosa comosa Fisch and their antioxide and $a$-glucosidase inhibitory activities. J Inner Mongolia Univ (Natural Science Edition). 2014;4:398-403.

12. China Pharmacopoeia Committee. Pharmacopoeia of the People's Republic of China, vol. 1. Beijing: Chemical Industry Press; 2010. p. 300-1.

13. Yokozawa T, Fujioka K, Oura H, Tanaka T, Nonaka Gl, Nishioka I. Decrease in uraemic toxins, a newly found beneficial effect of Ephedrae Herba. Phytother Res. 1995:9:382-4.

14. Kim IS, Park YJ, Yoon SJ, Lee HB. Ephedrannin A and B from roots of Ephedra sinica inhibit lipopolysaccharide-induced inflammatory mediators by suppressing nuclear factor-kB activation in RAW 264.7 macrophages. Int Immunopharmacol. 2010;10:1616-25.

15. Tao HM, Wang LS, Cui ZC, Zhao DQ, Liu YH. Dimeric proanthocyanidins from the roots of Ephedra sinica. Planta Med. 2008;74:1823-5.

16. Zang X, Shang M, Xu F, Liang J, Wang X, Mikage M, Cai S. A-Type proanthocyanidins from the stems of Ephedra sinica (Ephedraceae) and their antimicrobial activities. Molecules. 2013;18:5172-89.

17. China Pharmacopoeia Committee. Pharmacopoeia of the People's Republic of China, vol. 1. Beijing: Chemical Industry Press; 2010. p. 317.

18. Xie C, Veitch NC, Houghton PJ, Simmonds MSJ. Flavone C-glycosides from Viola yedoensis Makino. Chem Pharm Bull. 2003;51:1204-7.

19. Li DG, Zhang WG, Song YM, Li HF, Wu HJ, Jin YP, Zhou L. Studies on antibacterial constituents in Viola yedoensis. J Northwest Sci-TechUniv Agri For (Nat Sci Ed). 2006;34:87-90.

20. Cao J, Yin C, Qin Y, Cheng Z, Chen D. Approach to the study of flavone di-C-glycosides by high performance liquid chromatography-tandem ion trap mass spectrometry and its application to characterization of flavonoid composition in Viola yedoensis. J Mass Spectr. 2014;49:1010-24.

21. Editorial board of Chinese herb medicine. Chinese herbal medicine. Shanghai: Shanghai science and Technology Press; 1999. p. 3·477-8.

22. Xiong J, Bui V-B, Liu X-H, Hong Z-L, Yang G-X, Hu J-F. Lignans from the stems of Clematis armandii ("Chuan-Mu-Tong") and their anti-neuroinflammatory activities. J Ethnopharmacol. 2014;153:737-43.

23. Qi J, Zhang J, Sun Q, Li X, He P. Protective functions of traditional Mongolian medicines on experimental liver Injury. Acta Acad Med Nei Mongol. $1994 ; 16: 82-6$

24. Ma JN, Wang SL, Zhan K, Wu Z-G, Hattori M, Chen G-L, Ma C-M. Chemical components and antioxidant activity of the peels of commercial apple-shaped pear (fruit of Pyrus pyrifolia cv. pingguoli). J Food Sci. 2012;77:C1097-102.

25. Ma C-M, Nakamura N, Hattori M. Saponins and C-glycosyl flavones from the seeds of Abrus precatorius. Chem Pharm Bull. 1998:46:982-7.

26. Yerigui, Bumandorj B, Byambaakhuu N, Ma C-M. Pharmacokinetics of five different types of Safflower constituents in rat plasma after oral administration of Safflower powder. J Liq Chromatogr R T. 2015:38:1740-6.

27. He Q-Q, Yang L, Zhang J-Y, Ma J-N, Ma C-M. Chemical constituents of gold-red apple and their a-glucosidase inhibitory activities. J Food Sci. 2014;79:C1970-83

28. Wang CX, Yue LL, Xu HY, Uneer, Huang Y, Zhang H-P, Gao J, Ma C-M. Simultaneous quantification of 7 components in different punica granatum parts using ultra-high performance liquid chromatography-triple quadrupole mass spectrometry (UPLC-QQQMS). Food Science, published on line first.

29. Wei P, Huo H, Ma Q, Li H, Xing X, Tan X, Luo J. Pharmacokinetic comparisons of five ephedrine alkaloids following oral administration of four different Mahuang-Guizhi herb-pair aqueous extracts ratios in rats. $J$ Ethnopharmacol. 2014;155:642-8.

30. Zhang L, Li M-Y, Wang L-W, Gao J, Ma C-M. Isolation, identification, quantification and inhibitory activity on HCV protease of coumarins from Viola yedoensis. Can Chem Trans. 2013;1:157-64.

31. Porter LJ, Hrstich LN, Chan BG. The conversion of procyanidins and prodelphinidins to cyanidin and delphinidin. Phytochemistry. 1986;25:223-30

32. $\mathrm{Ma}$ CM, Sato N, Li XY, Nakamura N, Hattori M. Flavan-3-ol contents, anti-oxidative and a-glucosidase inhibitory activities of Cynomorium songaricum. Food Chem. 2010;118:116-9.

33. Fridovich I. Superoxide dismutases: defence against endogenous superoxide radical. Ciba Found Symp. 1978;65:77-93.

34. Cemek M, Aymelek F, Buyukokuroglu ME, Karaca T, Buyukben A, Yilmaz F. Protective potential of Royal jelly against carbon tetrachloride inducedtoxicity and changes in the serum sialic acid levels. Food Chem Toxicol. 2010;48:2827-32.

35. Zhang H, Yu CH, Jiang YP, Peng C, He K, Tang J-Y, Xin H-L. Protective effects of polydatin from polygonum cuspidatum against carbon tetrachlorideinduced liver injury in mice. Plos One. 2012;7:e46574.

36. Recknagel RO, Jr EA, Dolak GJA, Waller RL. Mechanisms of carbon tetrachloride toxicity. Pharmacol Therap. 1989:43:139-54.

37. Sohn EH, Koo HJ, Hang DTT, Jang S-A, Namkoong S, Lim JD, Kang SC. Protective effects of ellagic acid on ethanol-induced toxicity in hepatic HepG2 cells. Mol Cell Toxicol. 2013;9:249-56.

38. Priyadarsini KI, Khopde SM, Kumar SS, Mohan H. Free radical studies of ellagic acid, a natural phenolic antioxidant. J Agric Food Chem. 2002;50:2200-6.

39. Jeyadevi R, Sivasudha T, Rameshkumar A, Harnly JM, Lin LZ. Phenolic profiling by UPLC-MS/MS and hepatoprotective activity of Cardiospermum halicacabum against $\mathrm{CCl}_{4}$ induced liver injury in Wistar rats. J Funct Foods. 2013:5:289-98.

\section{Submit your next manuscript to BioMed Central and we will help you at every step:}

- We accept pre-submission inquiries

- Our selector tool helps you to find the most relevant journal

- We provide round the clock customer support

- Convenient online submission

- Thorough peer review

- Inclusion in PubMed and all major indexing services

- Maximum visibility for your research

Submit your manuscript at www.biomedcentral.com/submit
Biomed Central 